\title{
Assessing Matriculation College Students' Metacognitive Awareness Reading Strategies (MARS) in Biology
}

\author{
Arsaythamby Veloo ${ }^{1}$, Mariam A Rani ${ }^{2} \&$ Rosna Awang Hashim ${ }^{1}$ \\ ${ }^{1}$ School of Education and Modern Languages, University Utara Malaysia, (UUM), Sintok, Kedah, Malaysia \\ ${ }^{2}$ Kedah Matriculation College, Ministry of Education, Changlun, Malaysia \\ Correspondence: Arsaythamby Veloo, School of Education and Modern Language, University Utara Malaysia, \\ 06010, Sintok, Kedah, Malaysia. E-mail: arsay@uum.edu.my
}

Received: March 5, 2015 Accepted: May 3, 2015 Online Published: May 26, 2015

doi:10.5539/res.v7n7p453 URL: http://dx.doi.org/10.5539/res.v7n7p453

\begin{abstract}
This study examines the relationship between student's perceived use of Metacognitive Awareness Reading Strategies (MARS) in reading Biology books and corresponding Biology achievement. This study also identified the effective reading strategies that affect students' Biology achievement in a particular semester. This study selected 318 Biology students by random sampling which comprised 97 (30\%) male and 221 (70\%) female students who were studying in one of the Matriculation Colleges in Kedah state, Malaysia. This study use Metacognitive Awareness of Reading Strategies Inventory (MARSI) constructed by Mokhtari and Reichard (2002). Findings of this study show that there is a positive weak relationship between perceived use of MARS and their Biology performance in Matriculation Programme. This study also show that Global Reading Strategies and Problem-Solving Strategies are predictors but Support Reading Strategies is not a predictor of Biology achievement. In investigating the effects of strategies, Global Reading is the best contributor followed by Problem-Solving Strategies to predict Biology achievement. It is suggested that teachers learn how to practice reading strategy instruction in the classroom. Students themselves should learn MARS and apply them in their reading and focus more on Global Reading Strategies.
\end{abstract}

Keywords: MARS, metacognitive awareness, reading strategies, global strategies, problem-solving strategies, support strategies, biology

\section{Introduction}

Generally, most people acquire the skills to read, but not all readers are able to carry out the reading task effectively. While people are able to read without skill, they will be disadvantaged because it affects comprehension and retention, which consequently does not help to improve on previously acquired knowledge. Reading as an important skill as students need to read widely to acquire knowledge and gain new insights, Thus, students need effective reading skills to improve their learning process and cognitive development, which includes memorization and higher order thinking skills. Ozkan and Hatice's (2013) study on high school students showed that the two variables, that is, academic and individual, differ because of metacognitive awareness. Besides being attentive during lectures to get main ideas about the content, Biology students must read reference books to enhance their knowledge and understand the content further. Reading is important for students to relate the content to the real world and to their career. This is a must because before one is able to apply a concept in the real world, the person must first understand the things learned thoroughly before it is more likely to be transferred to a new related situation (Ormrod, 2008). In addition, the ability to read profoundly is very important because it influences academic achievement (Kuo-En, Yu-Ju, Chien-Mei, \& Yao-Ting, 2010). Although the contents in Biology are chunked into topics, they are still interrelated and need meaningful understanding. Therefore, students must understand one particular concept in order to understand another concept that will be learned in the subsequent subtopic or chapter. Study by Md Nor and Syed Muammar Billah (2012) found that students' understanding in photosynthesis was moderate based on the five level of understanding in secondary school. Students with poor comprehension claimed that they studied hard but performed poorly in tests. 


\subsection{MARS and Biology Achievement}

Metacognitive skill and control of study contribute to reading comprehension has been discussed by Cromley (2005). Recent studies have acknowledged the role of metacognitive awareness in reading comprehension (Fenfang, 2010). Although reading comprehension and monitoring develop intensively during higher elementary school (Kolic-Vehovec \& Bajsanski, 2007) the teachers should design a rich learning environment earlier in order to develop scientific reasoning (Yenilmez et al., 2006) and causal thinking (Berkant, 2009) as well as teaching learning strategies to increase awareness and usage of metacognitive knowledge (Caliskan \& Sunbul, 2011) to increase comprehension in reading. In another related study, Lau and Chan (2003) made a comparison between the ability of good and poor readers on the use of reading strategies for Chinese reading comprehension. They reported that reading comprehension is strongly related to the individual's ability to use reading strategies.

Compared to poor readers, good readers will readily use sophisticated cognitive strategies and metacognitive strategies to enhance reading comprehension. All these findings are in line with the one discussed by Vadhan and Stander (1994) which showed that high metacognitive ability will result in better academic performance. Application of meta-cognition has other significant effects. In Rysz (2004), the adult students that maximise the use of cognitive awareness and self-monitoring have better understanding of probability and statistics concepts.

Good reading comprehension with the application of metacognitive strategies leads to academic achievement (Fazal ur Rahman, Jumani, Chaudry, Chisti, \& Abbasi, 2010; Fenfang, 2010; Berkant, 2009; Caliskan \& Sunbul, 2011) including science or specifically Biology achievement (Cromley, Snyder-Hogan, \& Luciw-Dubas, 2010) and EFL reading achievement (Phakiti, 2003). Research results by Fazal ur Rahman et al. (2010) indicated that metacognitive awareness was significantly correlated with the performance of students in Chemistry. Fenfang (2010) in a study in China found that readers' metacognitive awareness of reading strategies was closely linked to their English language proficiency. In Phakiti (2003), the use of cognitive and metacognitive strategies had a positive relationship to the reading test performance where one who is highly successful in tests reported higher use of metacognitive strategy.

In a quasi-experimental study, Ngozi-Ibe (2009) found that metacognitive strategies were the most effective in enhancing science achievement in senior secondary school science classrooms. The finding of these researches is in line with the study by Mason and Nadalon (2005) that revealed that students with metacognitive competence tend to be successful students (Coutinho, 2006). Berkant (2009) suggested that educational activities can be designed based on the conclusion that students' academic achievement levels and reading comprehension scores are significant predictors of their meaningful causal thinking abilities.

\subsection{Global Reading Strategies and Biology Achievement}

The reading concept today is "text as process" rather than earlier notions of text being an "object" that was confined to decoding written symbols into sounds. For the abovementioned reason, people should develop reading skills as reading now is an active process including necessity to build strong interaction between reader and the text (Fenfang, 2010). Prior knowledge (Cromley et al., 2010; Yenilmez et al., 2006) and the ability to reason are important to determineconceptual understanding in Biology. This is consistent with the study byYenilmez et al. (2006) which showed that prior knowledge and reasoning ability is the main predictor of achievement in understanding photosynthesis and respiration in plants.

A study by Berkant (2009) showed that reading comprehension and causal thinking abilities are important to increase academic achievement. Relating the matter to Biology, abstract concepts in Biology require students to comprehend, relate the concepts and construct a coherent body of scientific knowledge as investigated by Yenilmez et al. (2006). This fact is strengthened by Mokhtari and Reichard (2002) that stated "I think about what I know to help me understand what I read" in the MARSI instrument. In conclusion, reading can be summed up as an interactive cognitive process in which readers interact with the text using their prior knowledge, cultural background and use appropriate strategies. This is consistent with the definition of reading by Fenfang (2010).

\subsection{Problem-Solving Strategies and Biology Achievement}

Readers will easily understand the text if the text contains familiar words or terms and understand the concepts. The potential problems arise when the readers encounter unfamiliar terms. This problem can be solved if the reader guesses the meaning of unknown words or phrases based on previous experience and it is one of the items in MARSI. This strategy is supported by Caposey and Heider (2003) who noted: "Understanding the meanings of words while reading helps children form pictures in their minds. Without vocabulary understanding, children may not be able to concentrate on the material they are trying to master and they may lose their train of thought" (p. 11). 
Deeper comprehension is also produced when students answered questions about the text and overcome reading problems using reading strategies as revealed by Brill, Falk, and Yarden (2004). Eye fixation also plays an important role to distinguish skilled readers from those who are not skilled. This fact is reported by van der Schoot, Vasbinder, Horsley and van Lieshout (2008) who showed that more successful comprehends invested more processing time in important rather than the unimportant words. These showed the importance of metacognition while reading. Unlike the unskilled readers who processed important and unimportant text elements, a successful reader actively constructs meaning and adjusts their reading speed based on their goal or text characteristics.

There are many researches done on reading since the late 1970s that take into account both the product of comprehension and more importantly the cognitive processes involved to gain the comprehension (Fenfang, 2010). Identifying the main ideas, understanding the content and connecting textual information with previous knowledge are among the ways to improve reading comprehension. This point is proven by McGinnis, Saunders, and Burns (2007) which showed that undergraduate students could provide the definition for rare words by understanding the passages given. They did it by understanding the text, searching the word related to the rare words and combining ideas to generate propositions linking explicitly the stated ideas.

\subsection{Support Reading Strategies and Biology Achievement}

One of the primary goals in language education is improving students' reading ability (Kuo-En et al., 2010). One of the important abilities is to be an active learner. In the constructivist theory of learning, co-operative learning asserts that people are active learners and must construct knowledge for themselves via interactions between individuals and the environment. Despite the effectiveness of conventional co-operative learning, Lan, Sung \& Chang (2009) reported that there were drawbacks of the strategies that prevented teachers from applying Computers and Literacy approaches to Chinese reading activities. One of the obstacles was the difficulty to track students' reading processes. The study also found that students needed various skills and methods to support their reading.

Mokhtari and Reichard (2002) have listed a few items in the questionnaire to promote active reading such as taking notes while reading, paraphrasing and underlining the information in the text. Due to the importance of the support system in reading, Kuo-En et al. (2010) introduced a wireless handheld system (WHS) that supports the individual and co-operative reading activities of students and helps teachers to implement reading strategy instruction in Chinese language classes. Students that apply going back and forth to find relationships among ideas will ascertain that the text model is coherent and richly connected and this strongly shows metacognition during reading as analyzed by van der Van der Schoot et al. (2008) and tested in the inventory used in this research that is item 24 .

\subsection{The Most Effective Strategy that Affect Biology Achievement}

Although all the three sub strategies under the overall MARS gave positive impact on reading attainment and thus academic performance, there are differences in the degree of impact towards the readers. It is important to study the best strategy to predict Biology achievement as Gersten et al. (2001) proved that reading comprehension of struggling readers increased after being taught the strategies that were used by good readers. This is one of the reasons why Lau and Chan (2003) studied the strategies used by good and poor readers in improving Chinese reading comprehension.

Cantrell and Carter (2009) who studied the same questionnaire found that better readers used global and problem-solving strategies more readily while there was a significant negative relationship between reading achievement and support reading strategies. Ronzano (2010) also arrived at the conclusion that students who used metacognitive strategies scored higher in reading comprehension than students who applied no strategy at all but only wrote notes or used some type of marks had a negative relationship with reading comprehension.

\subsection{Research Questions}

i) Is there a relationship between perceived use of MARS and Biology achievement of students in Kedah Matriculation College?

ii) To identify the effective reading strategies that affect students' Biology achievement.

\section{Methodology}

\subsection{Population and Sample}

This study consisted of 1300 students studying Biology in one of the Matriculation Colleges in Kedah State, Malaysia. 1013 (78\%) were female students while 287 (22\%) were male students. As suggested by Krejcie and 
Morgan (1970), the random sampling technique used in this study comprised 318 Biology students. The sample size for this study comprised 97 (30\%) male students and 221 (70\%) female students.

\subsection{Instrument}

Data collection was based on MARSI which is adapted from Mokhtari and Reichard (2002). The MARSI instrument consists of 30 items which measure Global Reading Strategies (13 items), Problem-Solving Strategies ( 8 items) and Support Reading Strategies (9 items). These strategies are used by students to seek support mechanisms when they read biology texts. For this purpose, students were asked to indicate their agreement on a five point Likert scale. The lowest score 1 indicates that the student never does this while the highest score of 5 indicates that the student always does this. Students were informed that their responses should only include strategies they used while reading Biology material during that particular semester.

\section{Results}

\subsection{MARS and Biology Achievement}

Table 1 shows a significant positive relationship $(\mathrm{p}<.01)$ between students' perceived use of Metacognitive Reading Strategies, Global Reading Strategies, Problem-Solving Strategies and Support Reading Strategies and their Biology achievement. Pearson correlation test between MARS and Biology achievement is significant ( $\mathrm{r}$ $=.27, \mathrm{p}<.01)$. This result showed there is a positive relationship between MARS applied by students and their Biology achievement. Application of MARS showed a weak relationship with Biology achievement $(r=.27)$.

Pearson correlation test between Global Reading Strategies and Biology achievement is significant $(r=.28, p$ $<.01)$. This result shows there is a positive relationship between the uses of Global Reading Strategies while reading and their Biology achievement. High Global Reading Strategies in studying Biology will result in high Biology achievement while low Global Reading Strategies applied in studying Biology will produce low achievement in Biology. Global Reading Strategies in reading Biology books showed a weak relationship with Biology achievement that is $r=.28$. The result of $r^{2}$ Global Reading Strategies will explain the Biology achievement by $7.84 \%$.

The Pearson correlation test between Problem-Solving Strategies and Biology achievement is significant $(r=.26$, $\mathrm{p}<.01)$. This result showed that there is a positive relationship between Problem-Solving Strategies applied by students and their Biology achievement. Application of Problem-Solving Strategies shows a weak relationship with Biology achievement $(\mathrm{r}=.26)$.

The Pearson correlation test between Support Reading Strategies and Biology achievement is significant $(r=.16$, $\mathrm{p}<.01)$. This result shows there is a positive relationship between the use of Support Reading Strategies while reading and their Biology achievement. Support Reading Strategies in reading Biology books show a weak relationship with Biology achievement $(\mathrm{r}=.16)$.

Table 1. Relationship between MARS, global reading strategies, problem-solving strategies and support reading strategies used towards biology achievement

\begin{tabular}{ll}
\hline Variables & BiologyAchievement \\
\hline MARS & $.27^{* *}$ \\
Global Reading Strategies & $.28^{* *}$ \\
Problem-Solving Strategies & $.26^{* *}$ \\
Support Reading Strategies & $.16^{* *}$ \\
\hline
\end{tabular}

$* * \mathrm{p}<.01$

\subsection{The Most Effective Strategy that Affects Student's Biology Achievement}

Table 2 shows the results of multiple regressions with the three factors in MARS as the independent variables and Biology achievement as the dependent variable. The regression model has a moderate value of determinant coefficient $R^{2}$ that is .09 . This result shows $9 \%$ of variance in Biology achievement can be explained by all of the three MARS factors collectively that is Global Reading Strategies, Problem-Solving Strategies and Support Reading Strategies. F statistic that tested $\mathrm{H}_{O}: R^{2}=0$ for this regression model is significant $(\mathrm{p}<.05)$ that is Biology achievement score $\left(R^{2}=0.09, \mathrm{p}<.05\right)$. It means there is at least one regression coefficient in each regression model which is significantly different from zero. $t$ value for two of the three MARS that are Global 
Reading Strategies and Problem-Solving Strategies are the significant contributors $(p<.05)$ towards Biology achievement but Support Reading Strategies is not significant $(\mathrm{p}>.05)$ to predict Biology achievement. Findings of this research show that Global Reading Strategies is the best predictor towards Biology achievement followed by Problem-Solving Strategies.

Table 2. Analysis of multiple regressions between biology achievement and metacognitive reading strategies

\begin{tabular}{lccccc}
\hline Metacognitive Awareness & \multicolumn{5}{c}{ Biologyachievement } \\
\cline { 2 - 6 } \multicolumn{1}{r}{ ReadingStrategies } & UnstandardizedBeta & StandardError & StandardizedBeta & $\mathrm{t}$ & $\mathrm{p}$ \\
\hline Coefficients(constant) & 1.15 & .33 & & 3.50 & $.00^{*}$ \\
Global & .34 & .12 & .23 & 2.86 & $.01^{*}$ \\
Problem-Solving & .21 & .11 & .15 & 1.97 & $.05^{*}$ \\
Support & -.10 & .10 & -.07 & -.95 & .35 \\
\hline
\end{tabular}

$* \mathrm{p} \leq .05$

\section{Discussion}

\subsection{Relationship between Perceived Use of MARS and Biology Achievement of Students in Matriculation College}

This fourth question is answered by a significant, positive correlation between students' overall perceived use of MARS as well as the three subcomponents and their Biology performance. This result is similar to results obtained from previous related studies (Fazal ur Rahman et al., 2010; Fenfang, 2010; Berkant, 2009; Caliskan \& Sunbul, 2011; Phakiti, 2003; Cromley et al., 2010; Coutinho, 2006). One of the most closely related researches was by Fazal ur Rahman et al. (2010) which focused only on metacognition and Chemistry performance. The achievement level for Chemistry was measured using a researcher made test. Although there were only weak correlations, the finding was still consistent with results found by Ngozi-Ibe (2009) that revealed metacognitive strategies were most effective in enhancing science achievement in senior secondary school. Many other researchers studied about metacognitive strategies during the reading process and their relationships with various fields such as reading achievement (Cantrell \& Carter, 2009; Lau \& Chan, 2003), Biology achievement (Cromley et al., 2010), Mathematics achievement (Rysz, 2004) and academic performance (Vadhan \& Stander, 2004).

Explanation on how metacognitive strategies can lead to academic achievement is hidden in the strategy items themselves. Active thinking and comprehension monitoring are important in reading comprehension. Cromley, (2005) and Mason (2004) found that thinking activities which occur before, while and after reading contributed to reading comprehension as one of predictors to students' academic achievement. This active learning also established the results by Berkant (2009) which documented a significant relationship between meaningful causal thinking and academic achievement as well as between meaningful causal thinking and reading comprehension. Eye fixation on important words discussed by van der Schoot et al. (2008) as an example in Global Reading Strategies was also a secret for successful comprehension as students recognized the important and unimportant things in the text.

\subsection{The Most Effective Metacognitive Strategy that Affect Biology Achievement}

As shown in the literature review, overall Metacognitive Reading Strategies, Global Reading Strategies, Problem-Solving Strategies and Support Reading Strategies had a positive impact on reading attainment and thus academic performance. In this research, the researcher evaluated the impact of individual sub strategies and found that Global Reading Strategies is the best contributor, followed by Problem-Solving Strategies as the significant contributors towards Biology achievement but Support Reading Strategies relatively is not the significant contributor. This gives a meaning that students that use the Global and Problem-Solving strategies will relatively have more opportunities to succeed in their Biology achievement. This finding is strongly supported by researches that found that good or highly skilled readers were reported to use global and problem-solving strategies to a greater extent than poor or less skilled readers (Mokhtari \& Reichard, 2002; Cantrell \& Carter, 2009).

Gersten et al. (2001) in their research indicated that the reading comprehension of struggling readers increased after being taught the strategies that are used by good readers. Thus, it is important to investigate the strategies that are most closely related to effective reading. This is one of the reasons why Lau and Chan (2003) studied the strategies used by good and poor readers in improving Chinese reading comprehension. 
Support Reading Strategies did not contribute much to student's achievement in Biology for the student participants in this research. This finding coincided with a study by Ronzano (2010) that showed that the use of a metacognitive method such as annotative note taking, for example "Circling, underling, or highlighting" currently used in public high schools, does not help to improve comprehension levels. In another study, Cantrell and Carter (2009) also reported that there was a negative relationship between Support Reading Strategies used.

\subsection{Implication}

The school could offer courses on MARS for teachers and students. When these courses are conducted, teachers and students would be exposed to the skills to be used during the reading process. If the course is especially conducted for teachers, the teachers should then teach the students about the skills. Strategies need to be taught over a sufficient duration for the training to be effective and be presented in a variety of texts to ensure students get used to the strategies. Furthermore, trained teachers should ensure that students understand how to apply the strategies in their reading tasks to strengthen their use. Besides, teachers must understand students' reading processes and help students to use reading comprehension strategies when reading to help students learn materials efficiently and thus retain the information longer. It is also suggested that teachers have to learn and put into practice appropriate reading strategies while teaching in the classroom. Therefore, the students will get more exposure to these reading skills and apply them.

\subsection{Conclusion}

Correlation analyses showed that the overall strategies and all the sub strategies are positively correlated with Biology achievement. In studying the effects of the strategies, Global Reading strategic reading behaviours is the best contributor to Biology performance followed by Problem-Solving Strategies. The study provides evidence that students' perceived use of strategies and metacognition while reading is important, and this should be applied to improve their learning experiences. MARS facilitate deep learning among students to improve academic achievement in Biology and other academic subjects.

\section{References}

Abdul, R. J. (2011). Permasalahan Kemahiran Membaca dan Menulis Bahasa MelayuMurid-murid Sekolah Rendah di Luar Bandar. Malay Language Education Journal, 1(1), 1-12.

Berkant, H. G. (2009). An Investigation of Students' Meaningful Causal Abilities in Terms of Academic Achievement, Reading Comprehension and Gender. Educational Sciences: Theory \& Practice, 9(3), 1149-1165.

Brill, G., Falk, H., \& Yarden, A. (2004). The learning processes of two high-school biology students when reading primary literature. International Journal of Science education, 26(4), 497-512. http://dx.doi.org/10.1080/0950069032000119465

Caliskan, M., \& Sunbul, A. M. (2011). The Effects of Learning Strategies Instruction on Metacognitive Knowledge, Using Metacognitive Skills and Academic Achievement (Primary Education Sixth Grade Turkish Course Sample). Educational Sciences: Theory \& Practice, 1(1), 148-153.

Cantrell, S. C., \& Carter, J. C. (2009). Relationships among learner Characteristics and Adolescents' Perceptions about Reading Strategy use. Reading Psychology, 30(3), 195-224. http://dx.doi.org/10.1080/02702710802275397

Caposey, T., \& Heider, B. (2003). Improving reading comprehension through cooperative learning (Unpublished master's thesis). Saint Xavier University and Skylight Professional Development Field-Based Master's Program, Chicago.

Coutinho, S. A. (2006). A Model of Metacognition, Achievement Goal Orientation, Learning Style and Self Efficacy. Northern Illinois University.

Cromley, J. G. (2005). Metacognition, Cognitive Strategy Instruction, and Reading in Adult Literacy. In J. Comings, B. Garner, C. Smith, J. Comings, B. Garner, \& C. Smith (Eds.), Review of adult learning and literacy: Connecting research, policy, and practice (Vol. 5, pp. 187-220). Mahwah, NJ US: Lawrence Erlbaum Associates Publishers.

Cromley, J. G., Snyder-Hogan, L. E., \& Luciw-Dubas, U. A. (2010). Reading comprehension of scientific text: A domain-specific test of the direct and inferential mediation model of reading comprehension. Journal of Educational Psychology, 102(3), 687-700. http://dx.doi.org/10.1037/a0019452

Examination Unit of Kedah Matriculation College. (2012). 
Fazal-ur, R., Nabi, B. J., Muhammad A. C., Saeed-ul, H. C., \& Fahim, A. (2010). Impact of Metacognitive Awareness on performance of Students in Chemistry. Contemporary Issues in Education Research, 3(10), $39-44$.

Fenfang, L. (2010). A Study of English Reading Strategies Used by Senior Middle School Students. Asian Social Science, 6(10), 184-192. http://dx.doi.org/10.5539/ass.v6n10p184

Gersten, R., Fuchs, L., Williams, J. P., \& Scottbaker. (2001). Teaching reading comprehension strategies to students with learning disabilities: A review of research. Review of Educational Research, 71(2), 279-320. http://dx.doi.org/10.3102/00346543071002279

Kolic-Vehovec, S., \& Bajsanski, I. (2007). Comprehension monitoring and reading comprehension in bilingual students. Journal of Research in Reading, 30(2), 198-211. http://dx.doi.org/10.1111/j.1467-9817.2006.00319.x

Krejcie, R. V., \& Morgan, D. W. (1970). Determining sample size for research activities. Educational and Psychological Measurement, 30(3), 607-610.

Kuo-En, C., Yu-Ju, L., Chien-Mei, C., \& Yao-Ting, S. (2010). Mobile-device-supported strategy for Chinese reading comprehension. Innovations in Education \& Teaching International, 47(1), 69-84. http://dx.doi.org/10.1080/14703290903525853

Lan, Y. J., Sung, Y. T., \& Chang, K. E. (2009). Let us read together: Development and evaluation of a computer assisted reciprocal early English reading system. Computers \& Education, 53(4), 1188-1198. http://dx.doi.org/10.1016/j.compedu.2009.06.002

Lau, K. (2006). Reading strategy use between Chinese good and poor readers: A think-aloud study. Journal of Research in Reading, 29(4), 383-399. http://dx.doi.org/10.1111/j.1467-9817.2006.00302.x

Lau, K., \& Chan, D. W. (2003). Reading strategy use and motivation among Chinese good and poor readers in Hong Kong. Journal of Research in Reading, 26(2), 177-190. http://dx.doi.org/10.1111/1467-9817.00195

Mason, L., \& Nadalon, C. (2005). Measuring High Students'Metacognitive Knowledge, skills and attitude through AILI Relationship with Gender, Grade, Curriculum and Achievement. University of Padua.

McGinnis, D., Saunders, N. N., \& Burns, R. J. (2007). Metacomprehension during Rare Word Comprehension. Reading Psychology, 28(3), 221-240. http://dx.doi.org/10.1080/02702710601186373

Md Nor Bakar, \& Syed Muammar Billah Syed Mohamad. (2012). Masalah pembelajaran pelajar sekolah menengah dalam mata pelajaran sains tingkatan 2 tajuk: fotosintesis. Retrieved November 2, 2012, from http://eprints.utm.my/10944/1/MasalahPembelajaranPelajarSekolahMenengahDalamMataPelajaranSainsTin gkatan2Tajuk.pdf

Mokhtari, K., \& Reichard, C. A. (2002). Assessing Students' Metacognitive Awareness of Reading Strategies. Journal of Educational Psychology, 94(2), 249-259. http://dx.doi.org/10.1037/0022-0663.94.2.249

Mokhtari, K., \& Sheorey, R. (2002). Measuring ESL students' awareness of reading strategies. Journal of Developmental Education, 25(3), 2-10.

National Assessment of Educational Progress. (2003). Results from the NAEP 2000 reading assessment. Retrieved February 25, 2004, from http://nces.ed.gov/nationsreportcard/reading/results

Ngozi-Ibe, H. (2009). Metacognitive Strategies on Classroom Participation and Student Achievement in Senior Secondary School Science Classroom. Science Education International, 20, 25-31.

Phakiti, A. (2003). A Closer Look at the Relationship of Cognitive and Metacognitive Strategy Used To EFL Reading Achievement Test Performance. Language Testing, 20(1), 26-54. http://dx.doi.org/10.1191/0265532203lt243oa

Pressley, M. (2000). What should comprehension instruction be the instruction of? In M. Kamil, P. Mosenthal, P. Pearson, \& R. Barr (Eds.), Handbook of reading research (Vol. 3, pp. 545-561). Mahwah, NJ: Erlbaum.

Pressley, M., \& Afflerbach, P. (1995). Verbal protocols of reading: The nature of constructively responsive reading. Hillsdale, NJ: Erlbaum.

Ronzano, S. J. (2010). Effectiveness of metacognitive strategies for improving reading comprehension in secondary students (Pro Quest Dissertations and Theses) (p. 115). University of California, Davis. Retrieved from http://eserv.uum.edu.my/docview/808572618? accountid=42599

Rysz, T. (2004). Metacognition in Learning Elementary Probability and Statistics (An unpublished Ed. D. thesis). 
University of Cincinnati, USA.

Schmitt, M. C. (1990). A questionnaire to measure children's awareness of strategies reading processes. The Reading Teacher, 43(7), 454-461.

Vadhan, V., \& Stander, P. (1994). Metacognitive ability and test performance among college students. The Journal of Psychology, 128(3), 307-307.

Van der Schoot, M., Vasbinder, A. L., Horsley, T. M., \& van Lieshout, E. M. (2008). The role of two reading strategies in text comprehension: An eye fixation study in primary school children. Journal of Research in Reading, 31(2), 203-223. http://dx.doi.org/10.1111/j.1467-9817.2007.00354.x

Yenilmez, A., Sungur, S., \& Tekkaya, C. (2006). Students' achievement in relation to reasoning ability, prior knowledge and gender. Research in Science \& Technological Education, 24(1), 129-138. http://dx.doi.org/10.1080/02635140500485498

\section{Copyrights}

Copyright for this article is retained by the author(s), with first publication rights granted to the journal.

This is an open-access article distributed under the terms and conditions of the Creative Commons Attribution license (http://creativecommons.org/licenses/by/3.0/). 